\title{
Pending Issues in Protection, Productivity Growth, and Poverty Reduction*
}

\author{
Omar Arias, Andreas Blom, Mariano Bosch, Wendy Cunningham, Ariel Fiszbein, \\ Gladys Lopez Acevedo, William Maloney, Jaime Saavedra, Carolina Sanchez- \\ Paramo, Mauricio Santamaria, and Lucas Siga
}

\begin{abstract}
This paper selectively synthesizes much of the research on Latin American and Caribbean labor markets in recent years. Several themes emerge that are particularly relevant to on going policy dialogues. First, labor legislation matters, but markets may be less segmented than previously thought. The impetus to voluntary informality, which appears to be a substantial fraction of the sector, implies that the design of social safety nets and labor legislation needs to take a more integrated view of the labor market taking into account the cost-benefit analysis workers and firms make about whether to interact with formal institutions. Second, the impact of labor market institutions on productivity growth has probably been underemphasized. Draconian firing restrictions increase litigation and uncertainty surrounding worker separations, reduce turnover and job creation, and poorly protect workers. But theory and anecdotal evidence also suggest that they, and other related state or union induced rigidities, may have an even greater disincentive effect on technological adoption, which accounts for half of economic growth. Finally institutions can affect poverty and equity, although the effects seem generally small and channels are not always clear. Overall, the present constellation of labor regulations serves workers and firms poorly and both could benefit from substantial reform.
\end{abstract}

World Bank Policy Research Working Paper 3799, December 2005

The Policy Research Working Paper Series disseminates the findings of work in progress to encourage the exchange of ideas about development issues. An objective of the series is to get the findings out quickly, even if the presentations are less than fully polished. The papers carry the names of the authors and should be cited accordingly. The findings, interpretations, and conclusions expressed in this paper are entirely those of the authors. They do not necessarily represent the view of the World Bank, its Executive Directors, or the countries they represent. Policy Research Working Papers are available online at http:/ / econ.worldbank.org.

\footnotetext{
* Executive Summary of Labor Stocktaking in the Latin American and Caribbean Region as part of
} the Global Labor Stocktaking exercise. 


\section{Introduction}

This paper synthesizes much of the research on Latin American and Caribbean (LAC) labor markets in recent years. Though covering many disparate topics, it does not attempt to be comprehensive, but rather stresses themes that have emerged as central in the work of the region. Several themes emerge particularly relevant to on-going policy dialogues:

1. Labor legislation matters, but markets may be less segmented than previously thought. The expanding literature in LAC on non-wage costs, firing restrictions, and nominal wage rigidities suggests that labor regulations do affect most labor outcomes. The magnitude of these effects is still in dispute. What does seem clear is that while wage rigidities have been instrumental in generating high unemployment during crises, the emerging view that an important part of informality may be "voluntary," suggests that the traditional focus on segmentation in the Harris-Todaro tradition may be overstated in normal periods.

However, there are substantial inefficiencies and distortions in the labor codes that give incentives to both workers and firms to avoid formal institutions. The value of benefitstraining, pensions, unemployment compensation- is often greatly misaligned with productivity levels and what workers or firms pay either explicitly or implicitly. This impetus to voluntary informality implies that the design of social safety nets and labor legislation needs to take a more integrated view of the labor market taking into account the cost-benefit analysis workers and firms make about whether to interact with formal institutions. This analysis incorporates the benefits of such interactions, the availability of informal substitutes, and the weighing of any greater risk exposure against the benefits of being independent and entrepreneurial.

2. The impact of labor market institutions on productivity growth has probably been underemphasized. Draconian firing restrictions increase litigation and uncertainty surrounding worker separations, reduce turnover and job creation, and poorly protect workers. But theory and anecdotal evidence also suggest that they, and other related state or union induced rigidities, may have an even greater disincentive effect on technological adoption which accounts for half of economic growth. In this sense, the labor market must be viewed as an key part of the National Innovation System. These issues take on a heightened importance in the context of more open economies. While there appear to be few long run adverse impacts of trade liberalization, reaping the benefits of greater integration will require greater attention the interactions between trade and labor regulation.

3. Institutions can affect poverty and equity, although the effects seem generally small and channels are not always clear. The majority of earnings differentials are generated by human capital endowments, not labor market institutions, and labor reforms have had indeterminate effects. Some regulations, such as minimum wages, clearly compress the earnings distribution, but if set too high can have opposite effects on household income distribution and poverty. There remain poorly understood differences in conditional earnings and patterns of employment along the lines of race, ethnicity and gender (although the evidence for discrimination based segmentation is weak) and related to unmeasured characteristics (early human capital, labor market connections). In particular, the observed female differentials and concentration in informal self employment seem driven by preferences related to household responsibilities, although in some cases labor provisions discourage women's regulated hiring.

Overall, the present constellation of labor regulations serves workers and firms poorly and both could benefit from substantial reform. 


\section{Trends over the last decade}

\section{a. Overall evolution ${ }^{1}$}

In the 1990s, employment grew faster than the working age population until $1998^{2}$ after which it declined. Despite higher GDP growth rates than in the 1980s, (3.9 v. 1.1 percent), the rate of employment growth was lower (2.9 v. 2.1), although Stallings and Peres (2000) argue that the employment-output elasticity during the 1990s was quite similar to what was observed during the 1960s and 1970s. There is therefore some disagreement around whether the region has entered a period of "jobless growth" (perhaps related to changes in output composition) or simply a cyclical slowdown. Further, this inverted-U employment growth obscures great heterogeneity in the region. The employment rate showed a downward trend in Argentina, Brazil, Ecuador and Uruguay while the reverse was true in Chile, Costa Rica, Dominican Republic, Mexico, Peru, Venezuela and Caribbean countries. Finally, these trends have occurred concomitant with a continuous expansion of labor force participation, with a particular increase in female participation from 44 to 50 percent between 1990 and 2000, that has exacerbated the challenge of creating sufficient good jobs.

Real wages increased in the formal sector of the economy in almost all Latin American countries during the 1990s. By 2000, the median wage for selected Latin American countries was 15 percent higher than the level observed in 1990, although in many cases, with the notable exception of Chile, still below the levels of the 1980s. ${ }^{3}$ The upward trend was particularly strong in Bolivia, Chile, Costa Rica, Guatemala and Nicaragua, where real wages in 2000 were well above 20 percent of what was observed in 1990. Formal sector real wages increased in Colombia, Ecuador, Paraguay, Peru and Uruguay, remained relatively constant in Argentina and Brazil, and clearly fell in Venezuela declining 35 percent between 1990 and 2000. The wage gains were likely driven by productivity increases in the modern part of the economy. Saavedra (2003) pools data from different sources for Brazil, Chile, Colombia, and Peru, and finds a clear positive correlation between labor productivity and real wages in manufacturing during the 1990s. Aggregate labor productivity, however, remained stagnant growing at an annual rate of -0.03 percent per year (IDB 2004).

LAC has some of the highest unemployment rates in the world.(ILO 2001) Unemployment rates have been rising across the 1990s in Argentina, Colombia, Chile, Uruguay, and Venezuela, experiencing a jump in 1998 when employment rates began to fall amidst expanding participation. By 2000, the median open urban unemployment rate among Latin American countries was 9 percent. Argentina, Colombia and Panama reached levels above 15 percent, while it continued to be particularly low in Mexico (2.2\%). In Caribbean countries for which data are available, urban unemployment decreased during the 1990s. Increasing urban unemployment tends to be less driven by shedding in the formal sector, and more due to reduced access to the market, especially by the young.

However, the incidence of long-term unemployment has not increased significantly. (see IADB 2004). The incidence of longer unemployment spells is still low compared to Eastern European countries and other developed countries; during the 1990s the incidence of unemployment spells longer than one year was 11 percent among Latin American countries but 42 percent among

\footnotetext{
${ }^{1}$ This section draws on background work by Saavedra

${ }^{2}$ based on information from household surveys compiled by the International Labor Organization (ILO).

${ }^{3}$ CEPAL's early evaluations found if anything a positive impact on wages (see Weller 2000) Stalling and Peres (2000).
} 
Continental Europe and Eastern European countries. However it is higher than in the U.S, where it affects only 7.4 percent of the unemployed. The continued low rate may reflect the possibility to enter the informal sector and/or discouraged workers moving into inactivity (IADB) although Bosch and Maloney (2004) find that such movements tend to be procyclical, for example, reaching their nadir during the crisis in Mexico.

Part of the fall in employment and rise in unemployment the early 2000s may be due to decreased downward real flexibility of wages and the unfinished business of macro stabilization. As Gonzalez (1999) has noted, lower inflation rates throughout the region imply that the adjustment to a recession occurs through quantities instead of prices as might traditionally have occurred. This loss of flexibility also implies that other rigidities may have become more binding. More generally, many countries have been struggling with managing the expectations generated by the unfinished business of macro stabilization, including rigidities introduced by employing exchange rate anchors, the disruption caused by their traumatic abandonment, or recessions associated with the collapse of under regulated financial sectors.

Despite growth in employment during the nineties, the share of workers covered by formal sector benefits has diminished. As summarized in Saavedra (2003), several characteristics that may be related to job quality showed negative trends. The percentage of workers with access to health and pension benefits has diminished in most countries, the share of temporary contracts within the formal sector has increased, and turnover has generally increased.

\section{b. Trade Liberalization ${ }^{4}$}

In many countries, globalization has received special attention as a cause of increased unemployment. Isolating the impact of trade reform is complex since cuts in tariffs and quotas have occurred concomitant with, and in fact, as parts of stabilization plans seeking to eliminate the adverse expectational consequences of long standing macroeconomic balances. That said:

Increased openness does not appear correlated with unemployment: Beyond the initial adjustments there appears to be little evidence to indict trade reforms for causing higher rates of unemployment. Anecdotally the region's more aggressive trade integrators - Chile and Mexico have, if anything, among the most modest rates of unemployment. Marquez and Pages (1998) argue that while liberalization appeared to reduce employment per unit, the expansion of production makes the overall impact of liberalization on employment statistically insignificant. In fact, IADB (2003), using household surveys for 10 countries, argued that it increased employment and did not have any significant impact on unemployment. Their overall conclusion is consistent with the finding that, internationally, there is no significant relationship between openness of countries (exports plus imports over output) and their levels of unemployment.

Or with informality. The tendency towards somewhat higher informality does not seem particularly due to trade. Though the sector has absorbed some of the workers displaced by foreign competition, this is probably not the entire story as discussed below. Argentina has seen a rise in informal salaried work (Gasparini 2000) but the trend predates liberalization by half a decade suggesting other forces. More exposed sectors tend to be more formal throughout the region and there is relatively

\footnotetext{
${ }^{4}$ This section draws heavily on Maloney (2002).
} 
little evidence of increased subcontracting (Sanchez, Joo and Zappala 2001) in Mexico that would suggest a large subcontracting out of formerly formal jobs for competitiveness purposes.

Wages have probably benefited over the medium term: Conditional wages are, in fact, higher in industries more exposed to trade. IADB (2004) documents numerous studies suggesting employment declines during the adjustment process, particularly in industries with substantial rents, and among specific demographic groups but assert that there is no empirical basis for a permanent decline. The widening skill earnings gap discussed below is observed in all countries that liberalized their economies, but seems less directly related to trade per se than to greater skill biased technology flows common around the world.

The emerging jobs seem desirable. Though sample sizes are small, surveys of maquila workers suggest these jobs are as attractive (see for example, Sargent and Matthews 1999) or more so than alternatives and Feenstra and Hanson report (1996) that such firms tend to demand more in terms of skills than other industries. Employees in the flower industry in Ecuador and the fruit industry in Chile earn more and have more stable incomes than those in traditional industries (de Ferranti, et al 2002)in the agricultural sector. Sanchez, Joo and Zappala (2001) argue that micro firms that are more closely linked to large (and hence more likely to be tradeables producing) firms earn premia of around 30 percent on non-linked micro firms.

Worker risk Despite concerns that trade liberalization would lead to greater worker uncertainty (Rodrik 1997), at present there is little evidence of it. Most recently, IADB (2004) finds no evidence of reallocation between industrial subsectors and Wacziarg (2001), using a global panel including LAC, finds only weak and borderline significant effects. One key transmission mechanism, an increased wage elasticity of labor driven by higher product elasticities, has not materialized in Colombia or Chile and shows only fragile appearance in Mexico (Fajnzylber and Maloney, forthcoming). Further, extracting the permanent component of worker income variance in the Mexican urban labor survey, Krebs, Krishna and Maloney (2004) find no increase in the permanent component of risk, but a transitory increase corresponding to the adjustment period.

In sum, there are transitory impacts of trade liberalization, but openness does not appear correlated with many of the expected evils. There is actually surprising low reallocation after liberalization, no permanent changes in unemployment, mixed impacts on wages in the medium term, an expansion of the wage gap, and overall increased job quality in exporting and import competing industries.

\section{Further work}

- Measurement of labor market outcomes: There is some concern about lack of crosscountry comparability of labor market indicators. It may be that Mexico's consistently lower unemployment rates reflect a better functioning labor market than, say than that of Argentina with much higher secular levels, or it may perhaps reflect measurement differences, including those arising from how workers approach the standard survey questions.

- Complementary policies: Recent work in the region, particularly on NAFTA, increasingly stresses that trade reform offers opportunities, but it is not a panacea that obviates reforms in other areas. Exposure to international competition may make certain labor market distortions more critical, but as yet there is little work studying the necessary complementary policies in the areas of legislation, collective bargaining, skill accumulation, and active labor market policies. It goes without saying that raising the 
quality of human capital has been a critical ingredient in the East Asian Miracles' success in the world market.

- Are labor market rigidities preventing more adjustment? As noted above, what the IADB found surprising was the low level of intersectoral allocation of workers and, overall, the literature has found modest changes in rates of turnover. Again, a much broader agenda is required on the impact of regulation on technological adoption, that would, in all probability, increase both flows, and the ability of small firms to exploit economies of scale.

\section{Protecting Workers}

The issue of the optimal design of worker protections is complicated and the region has made some small progress on the issue in recent years. This section discusses the importance of the phenomenon of informality, the deficiencies of extant employment protections, the impact of nonwage costs, the employment and poverty implications of minimum wages, and the impact of unions. Heckman and Pages (2004) have summarized much of the recently emerging literature and only select references will be mentioned here. A theme throughout this section is that the study labor legislation needs to move away from a traditional focus on segmentation and job creation in a static sense, toward a focus on the labor market as an integral part of the National Innovation System, the constellation of institutions and firms that are involved in dynamic productivity gains through technological progress. (See De Ferranti et al 2003).

\section{a. Informality ${ }^{5}$}

The informal sector merits treatment first not only because it is ostensibly the largest mass of unprotected workers, but also because recent evolution in thinking has implications for the design of social protection systems.

The informal sector comprises both workers preferring formal sector employment (involuntarily informal) and those preferring the qualities of unregulated entrepreneurship. In motivation surveys from Brazil and surveys of workers leaving formal employment in Mexico, 60-70\% report preferring informal self employment for reasons of independence and higher earnings. ${ }^{6}$ Though difficult to measure job characteristics make wage comparisons faux amis for establishing segmentation, numerous studies have established higher earnings among informal workers, particularly the urban self employed. ${ }^{7}$ Recent studies for Brazil and Bolivia that attempt to control for selectivity into the sector find that predominantly informal salaried workers at the bottom of the salary scale within any skills set face a significant wage disadvantage vis-á-vis formal jobs. ${ }^{8}$ Attempts to compare welfare more directly find a premium to being informally self employed in Bolivia (Arias and Sosa 2004), consistent with the sociological evidence from Mexico finding self employment is often considered a step up from salaried work. As discussed below, women appear to

\footnotetext{
5 See background papers by Maloney and Saavedra

6, Cunningham and Maloney (2002), Maloney (2004)

${ }^{7}$ See Yamada (1996), Marcouiller, Ruiz and Castilla and Woodruff (1997), Maloney (1999), Saavedra and Chong (1999), Gong and van Soest (2002).

${ }^{8}$ Tannuri and Pianto (2003) and Tannuri, Pianto and Arias (2004).
} 
find that self employment allows a better balancing of home and work responsibility. For some workers, informality offers more flexibility and mobility opportunities than the patronage-tenuredbased formal sector, for instance, Bolivian indigenous workers do not face earnings gaps with respect to non-indigenous in informal jobs contrary to the formal sector. ${ }^{9}$ A sizable group of informal salaried workers would value at least partially the benefits that usually are tied with a formal labor contract, but they cannot afford these benefits due to their lower productivity and/or due to the fact that benefits are usually bundled with other undesired but costly programs. In this light, the equation of "decent work" to formal work is probably not helpful. The informal sector is very heterogeneous and maybe best approximated by an upward tier of largely voluntarily informal workers (including most selfemployed and some informal salaried) and a smaller lower tier for which the sector functions as a safety net. The relative size of these groups may vary across countries depending on overall productivity levels and labor institutions.

The relative size of the informal sector is, in the long run, related to demographic and productivity related factors rather than to distortions. Crude regressions using pooled OECD/LAC data sets show that the relationship of the share of self employment and formal sector productivity is log linear and most of the variance is driven by demographic variables, suggesting the that decision to go into self employment is partly driven by the opportunity cost measured in terms of formal employment foregone. Firing cost measures and social security taxes appears significant but of second order. ${ }^{10}$ Wage gaps between workers in small and large firms in the region are similar to those in the U.S (IDB 2004).

In the short to medium term, sector size does reflect the macro economic situation and how much adjustment occurs through quantities v. real wages and the incentives of firms to become formal. The large expansion of the sector in Colombia after 1995 occurred concomitant with a dramatic fall in earnings relative to the formal salaried sector, suggesting that substantial nominal rigidities were preventing the necessary adjustments to crisis. Further, as Rama and MacIsaac (1999) point out, laid off workers from privatizations or other downsizing frequently wind up in informal self employment. On the other hand, in Mexico, the informal self employment sector expanded from 1988-1991 concomitant with a relative rise in its earnings, suggesting a boom in the non-tradeables sectors that was particularly attractive to informal entrepreneurs. The overall sluggish wage growth in the informal sectors in many countries suggests that the sector has been hit hard by recessions. Furthermore, high compliance costs of regulations to start and run a business and low benefits tilt the cost-benefit ratio of informal entrepreneurs to remain informal. Costly procedures for registration and business expansion, negative tax incentives and the poor performance of public and private services (including the judiciary and credit access) yield low benefits to become formal. Hence, reforms should take an integrated view of how to change the incentives for both workers and firms to become formal.

Patterns of entry, exit and mortality in informal self employment are similar to those in the US. Patterns of entry into self employment are observed later in mid-life, consistent with the existence of credit constraints-the sector is not a sector of entry. Evidence from Argentina, Brazil, Mexico, and Peru, suggest that young workers engage in informal salaried employment, generally for short periods of time, while self employment is most likely among middle aged workers. Overall the "precariousness" arising from high rates of turnover of the sector may simply be due to high mortality rates found among small firms everywhere.

\footnotetext{
${ }^{9}$ Tannuri, Pianto and Arias (2004).

${ }^{10}$ Maloney (2001)
} 
Nor are informal sector employees necessarily uncovered. Evidence discussed below suggests that the minimum wage is, in fact, more binding in the informal salaried sector than the formal in many countries. Further, in Peru, casual evidence suggests that informal sector workers are covered by vacation benefits and receive the holiday bonus salary. Both lend support to the idea that much of the informal sector is not necessarily inferior, but offers a package of characteristics that may dominate - in the cost benefit decision making process of workers and firms- that in the formal sector. When we add the observation that the mean stay in the sector is very short, generally around a year in Argentina, Brazil and Mexico; that many informal salaried workers are working for relatives; and that substantial vocational and on the job training appears to occur in the sector, the classic view of a stagnant pool of rationed out and unprotected workers appears to be inadequate. As a first approximation, it may be better to consider it as largely an entry sector for poor and poorly educated workers that corresponds to the kinds of temporary jobs that youth in the industrial countries take as they shop for careers, although the earnings potential of many informal salaried is constrained by the low and stagnant productivity of small firms in the region.

\section{This discussion implies a substantial change in the labor market research agenda:}

- Discussions of job quality must move away from dichotomies based purely on coverage by formal institutions. A voluntary, unconstrained move into informality implies a superior job, even without benefits. A more complete set of diagnostics of job quality need to be developed.

- A substantial share of "voluntary" informality suggests that the level of segmentation may be substantially less than previously imagined and the dualistic paradigm overstressed. Arguing that $50 \%$ of the labor force is rationed out of formal employment at a demand elasticity of approximately 0.4 implies very high levels of wage rigidity. If, however, much or most is voluntary, the level of segmentation may be lower or nonexistent. As discussed, Mexico has a large informal sector despite little evidence of either minimum wage or union induced nominal rigidities.

- Labor market policy, and social protection policy more generally, needs to be viewed in a more integrated framework to ensure incentives are correct across the entire labor market. Saavedra and Chong (1999) and Levenson and Maloney (1996) both argue that the decision to comply with regulations as a firm can be understood as the result of weighing the costs and benefits of participation in social institutions more generally. The same calculus applies to workers who will weigh the value of social benefits relative to what arrangements can be made informally, against the tax, implicit or explicit, that being a registered employee implies. As examples, training contributions in Colombia, for example, are 2 percent of payroll but are not valued by firms or workers; health care and social security systems are notoriously inefficient, at one point estimated at 25 percent of revenues in Mexico, and of poor quality; and pension funds are frequently insolvent and often have a strong redistributive dimension. Thus, reforms should focus on the most binding constraints and consider the interactions between labor regulations and other aspects of the investment climate affecting the incentives to become formal.

The implications for policy are critical. If most workers are rationed out of formal jobs, then expansion of social safety nets is welfare improving. However, in the alternative view offered, expanding inefficient or narrowly designed policies may backfire and 
actually expand the number of informal. As an example, extending basic universal basic medical care not linked to other dimensions of formality, while perhaps desirable to reach those truly excluded, is implicitly a subsidy to those contemplating leaving formal protections for informal entrepreneurship. Overall, this probably justifies a shift in emphasis from the burden of social protections, and labor market rigidities overall, to an evaluation of their efficiency and design. Since workers are likely to weigh the package of formal sector protections, social policy needs to treat the entire protection system as a whole, integrating the various complementarities among government programs as well as the private alternatives for protection through community or private mechanisms.

Moreover, besides reforms to improve the overall investment climate, there might be room for bundled interventions to give smaller firms flexibility and align their incentives to participate in formal institutions. One example is special labor provisions to accommodate non-wage costs for smaller firms and incentives (e.g., partial tax credits, facilitated access to market-based financing, business support services) to become formal in other dimensions (being registered, reporting taxes). These should be engineered in a way that helps reduce monitoring costs by inducing firms to self-reveal their scale of operations (for example, requiring compliance with minimum tax and labor regulations to obtain bidding rights in government purchases and access to business development programs) and phased out gradually as firms increase their scale of operation. Learning from the experience of welfare reform and small business support programs in the U.S and similar experiences in other countries, a substantial research project is in order to develop such an approach.

- Issues of productivity enhancement merit as much attention as reducing rigidities induced unemployment or informality. Informal employment in firms of relatively low technology and capital intensity can only be attractive if the overall level of labor productivity in the formal sector is low also. To the degree that current legislation impedes investment in physical or human capital, or prevents the efficient organization and operation of firms, it perpetuates the low levels of productivity throughout the economy. Many of the unanswered questions surrounding this topic are discussed below in greater specificity.

\section{b. Existing employment protection legislation}

Employment protection legislation regulates (i) available contractual forms, (ii) special rules favoring hiring of particular groups, (iii) conditions for firing, and (iv) worker compensation and other firing costs. Conceptually, for reasons detailed below, the present system of proscribing firing of workers, except for gross misconduct, probably serves both workers and firms poorly. However, the literature has encountered a series of empirical problems that make it difficult to draw causal relationships and extract general conclusions: difficulties endemic to cross-country analysis, problems of creating standardized measures of de jure employment protection, and the sometimes limited connection of de jure to de facto enforcement. That said:

There is no clear cut evidence that employment protection increases overall employment. Rules that protect employment and make firing difficult act as a tax on labor that, theoretically, may lead to reduced firing during bad times and hiring during good times, as well as having a negative impact on the creation of new businesses. The net effect of regulation on employment depends on the relative 
importance of these different sources, and thus remains an open empirical question. The international cross-section evidence, while mixed, generally concludes that employment protection reduces net employment. ${ }^{11}$ The evidence from Latin America, at this point, it also mixed and is best summarized in Heckman and Pages (2004). In their own work they find evidence that the level of indemnities for dismissal decreases employment in the OECD although, in contrast to their previous findings with smaller samples, it has no significant impact in LAC. They speculate that this may be due to the high level of heterogeneity in worker characteristics across countries. Mondino and Montoya (2000), and Saavedra and Torero (2002) find a negative relationship for Argentina and Peru respectively. In contrast, Pages and Montenegro (1999), and Paes de Barros and Corseuil (2000) find no significant effect for Chile and Brazil, respectively.

Employment protection does reduce turnover. More restrictive legislation is expected to reduce hiring and firing so we should observe that it also reduces labor turnover since employed workers will tend to spend more time on a particular job. Though LAC shows much higher levels of turnover than the OECD, in spite of more stringent firing restrictions, Maloney (2001) argues that the systematic difference largely disappear once the lower level of education in LAC is accounted. However, the Marquez index of job protection does indeed lead to higher tenure. At the countrylevel, Kugler (2000) and Torero (2004), and Gonzaga (2003) provide evidence that higher protection is associated with lower turnover in Colombia, Peru and Brazil, respectively although Paes de Barros and Corseuil (2001) do not find a significant relationship for the latter. It is also important to note, however, that hiring and firing can occur either because a worker joins or leaves an existing firm, or because a firm is created or destroyed. Available empirical evidence tends to confirm the latter channel of adjustment where firing costs are high. ${ }^{12}$ In Latin America, the report Good Jobs Wanted (IDB, 2004) confirms that worker flows are high in all countries, relative to the OECD, irrespective of the level of employment protection granted by their legislation. The authors argue that this result suggests that employment creation and destruction is closely linked to firm creation and destruction, rather than to hiring and firing by existing firms.

The evidence on the net impact of lower turnover, and lower job creation is, predictably, also mixed. The international evidence is again mixed. ${ }^{13}$ In Latin America, Kugler (2000) finds a positive and significant relationship between both variables for the case of Colombia. Similarly, Pages and Montenegro (1999) and Montenegro and Pages (2004) show that in Chile higher employment protection leads to a decline in the demand for unskilled workers.

Employment protection changes the composition of employment. When hiring and firing becomes difficult, firms will tend to hire and retain only those workers who are viewed as highly productive, relative to their cost. Because education and experience, which generally appear to be positively correlated with labor productivity, vary across demographic groups this implies that firms will be more willing to hire certain types of workers than others. For the OECD, Nickell (1997) finds that higher protection is associated with lower levels of aggregate employment, but finds no evidence of

\footnotetext{
11 Lazear (1990), Grubb and Wells (1993), Addison and Grosso (1996), Nickel (1997), Nicoleta and Scarpetta (2001), and Addison and Texeira (2003) find a negative relationship between employment protection and the employment rate using data for various countries, while Addison, Texeira and Grosso (2000) and Freeman (2001) find no relationship between the two. A summary of the literature by Addison and Texeira (2001) concludes that, taking into account all available evidence, employment protection reduces net employment.

${ }^{12}$ Using data from OECD countries, Blanchard and Portugal (2001) show that more restrictive legislation tends to reduce labor turnover in the short-run, but not in the long run (more than 12 months).

${ }^{13}$ Elmeskov, Scarpetta and Martin (1998), Lazear (1990), and Addison and Grosso (1996) find a positive relationship between employment protection and unemployment, while Blanchard (1998), Nickell (1997) find no significant relationship. Addison and Texeira (2001) then disaggregated unemployment in three components and find that employment protection increases structural unemployment, long-term unemployment and youth unemployment.
} 
significant differences across groups. Montenegro and Pages (2004) find that higher protection in Chile is associated with lower employment rates among young workers, women, and unskilled workers. Marquez (1998) finds that more stringent regulation coincides with a larger percentage of self employed workers, a finding confirmed by Maloney (2001), although the estimated impact was small compared to other education, productivity, or demographic variables.

Theoretically, restrictions should reduce productivity growth although at present the evidence is sketchy: The literature on the impact on productivity growth is thin at the international level and thinner still in Latin America. Hopenhayn and Rogerson (1993), using a general equilibrium model for job creation and destruction, find that policies that interfere with the natural process of job creation/destruction at the firm level are quite costly in terms of average productivity and, more generally, in terms of aggregate welfare. ${ }^{14}$ Parente and Prescott $(1991,2000)$ argue that TFP differences dominant differences in per capita GDP and that firing costs are one of the policies that increase the power of inside labor in a number of industries to resist changes in work practices and adoption of new technologies. Capelli (2000) and Hobjin and Jovanovic (2001-HJ) also show that stringent hiring and firing restrictions raise the cost of labor adjustments, which is often required after innovation occurs. A more recent analysis provided by Scarpetta and Tressel (2004), using firm OECD data, finds an impact of firing regulations on productivity and technological via its impact on the incentives to innovate and to adopt new technologies. ${ }^{15}$ For Latin America, the results are very preliminary: Forthcoming research by Gracia and Santamaría (2004) find that at the aggregate level (national TFP), the substantial reduction of firing costs that occurred in 1990 in Colombia had a positive effect on the evolution of productivity growth. There is also a yet unexplored potential that poorly designed legislation discourages micro and small enterprises from participating in other formal institutions (e.g., credit, training) and thus capitalize on scale economies and innovation.

\section{Further Work}

- Identifying the true costs of job protection. Many of the findings above prove unstable or at the very least are probably not good guides on the true magnitudes of the impact of employment protections. In particular, though an important literature stresses the productivity implications of legislation, to date documentation of these effects has been difficult.

\footnotetext{
${ }^{14}$ In effect, HR find that a tax on dismissals equal to one year's wages reduces average productivity by $2 \%$. Consumption, on the other hand, is reduced by about $2.5 \%$ (these are long run-equilibrium effects). They find that the tax on job destruction creates a distortion that encourages firms to use resources less efficiently, with the result that productivity drops and fewer resources are devoted to the market sector of the economy. Being more specific, HR find that the channel through effect relates to the fact that when no dismissal costs are present, firms make their employment decisions based solely on the value of the marginal product of labor and the size and sign of the idiosyncratic shocks faced by the firm. However, when such costs are introduced, firms also base their employment decisions on the amount of labor used on previous periods, distorting such decision and making the aggregate marginal product of labor deviate from its equilibrium value. An important point is that in these base calculations, in which the tax on dismissals is set at $20 \%$ of the wage, the total costs of such tax are small (about 5\% of the payroll), and even then the productivity effects are large. Thus, the authors stress the importance of these distortions and claim that focusing only on their employment effects is a mistake.

15 They mention three channels through which it is possible to observe the influence of legislation on innovation: (i) the system of industrial relations; (ii) the cost of hiring and firing workers; and (iii) the possible interactions between industry-specific technological characteristics and employment protection legislation, which lead to different human resources strategies.
} 
- Turnover and human capital accumulation. Facilitating worker separations on either side of the transaction may reduce the incentive of firms to invest in training. The challenge is to understand how employment protection can provide some security to workers without introducing rigidities in the labor market and without reducing incentives for firms' training investments. This is the concern underlying various discussions of the hyperactive Latin labor market and whether it must be slowed down somehow.

\section{c. Designing New Employment Protection Mechanisms ${ }^{16}$}

Unemployment safety nets are increasingly important to LAC for both economic and political economy reasons. Perhaps because most countries legally proscribe firing workers for anything but gross misconduct, safety nets for unemployed workers have generally been weak and poorly designed. Arguably, several factors have made their reform increasingly urgent. First, the existing system serves neither firms nor workers well. The legal barriers and the uncertainty and legal hassles to adjusting the workforce for economic reasons discourages innovation and the corresponding gains in worker productivity. However, politically increased flexibility on the separations front must be packaged with credible improvements in the safety net. Second, the indemnizations promised workers in the case of unjust dismissals or firm failures pool risk in the least efficient fashion at the firm level: a firm on the verge of closing is least able to afford to pay workers. Even in healthy firms, high litigation costs and uneven enforcement means workers in practice get less than dictated by law. And the informal sector is, by definition, uncovered by formal protections. Third, declining inflation rates reduce the possibility of coordinated declines in real wages and increasingly force adjustment through quantities. ${ }^{17}$ Fourth, although the data as yet do not suggest large effects as discussed above, foreign competition may be expected to increase the rate of firm failure and necessary workforce adjustments.

Appropriate employment supports must be designed with an eye to cost. If they are financed out of labor taxes, they may impede employment growth. In fact, as is the case with all labor taxes, the true incidence depends on how much workers value the income security and how much of the implicit tax is considered a pure tax, combined with nominal rigidities in the system.

...and optimal balancing of risk pooling and moral hazard. The well documented moral hazard issues surrounding insurance manifest themselves, most obviously, in reduced job search. In the literature, the tradeoff between the greater pooling and higher monitoring costs suggests that systems should focus on self insurance in the case where shocks are small and frequent and risk pooling mechanisms when shocks are infrequent and devastating. To date, the research on Latin America has been better at documenting the moral hazard issues than identifying the precise structure of risk although generally, among the poor, unemployment is fairly frequent and short lived. In this case, self insurance type system of individual saving accounts (ISA) where workers, the firm, or the government contribute to an account that the worker owns has been thought to offer the best

\footnotetext{
${ }^{16}$ See background note by Cunningham (2004), De Ferranti et al (2000)

${ }^{17}$ Adjustment to the Mexican Peso crisis of 1995 was achieved by freeze nominal wages and allowing inflation to erode their real value spreading the costs across the entire population. Unemployment rose relatively little and reached the lowest levels in decades within 3 years Maloney, Cunningham and Bosch (2004). Conversely, the burden of crisis was absorbed by the disproportionately poor unemployed in Argentina and Colombia where real wages could not or were note permitted to erode. World Bank (2001) Household Risk, Coping Strategies, and Coping in Urban Argentina Report No. 22426-AR
} 
combination of ensuring funds for smoothing shocks and search while mitigating moral hazard. ${ }^{18}$ Kugler (2004), for instance, shows that moving to ISAs in Colombia led to shorter unemployment periods and higher post-unemployment wages. ${ }^{19}$ The Brazilian program where workers could access their account only upon firing appeared to create the perverse incentive to lobby to be fired and the alternative pago a todo evento contemplated in Mexico may in fact stimulate turnover that perhaps discourages investments in human capital.

In Brazil, which also had a true unemployment insurance program (UI) that pools risks and hence might be more prone to moral hazard, no improvement in matching, evidenced through higher wages was found, nor did the unemployment spells lengthen. However, those who collect UI were more likely to become self employed than those who did not, suggesting that UI is an alternative source of (hard to obtain) credit for firm start-up. ${ }^{20}$ Similar results are found for training programs in Mexico. ${ }^{21}$ Both examples suggest, again, the need to view the market in an integrated fashion- if poor formal sector workers seek to start their own businesses, UI programs designed without this in mind can facilitate a movement to informality.

Informal insurance mechanisms still dominate household coping strategies. As Fiszbein (2004) notes, Latin America has evolved something a truncated welfare state where formal social protection schemes are concentrated among the better off leaving large segments of the population not only poor but without defense against shocks.

Private mechanisms may be more effective than thought. Despite understandable, although perhaps unhelpful assertions of their imperfection, informal mechanisms seem moderately effective alternatives to formal coverage and the primary source of insurance in countries with limited UI mechanisms and large informal sectors. ${ }^{22}$ In a striking example from Europe, Bentolila and Ichino (2000) argue that household incomes fell substantially less in Italy and Spain in response to unemployment of the household head than it did in Germany where formal protection systems were more advanced. That said, the informal labor market itself cannot be complacently viewed as a safety net: in Argentina, Brazil and Mexico, the sector generates roughly $60 \%$ of the flows into unemployment (consistent with self employed sectors showing high mortality rates everywhere) and generated the majority of the increase in unemployment during the Mexican crisis. ${ }^{23}$ However, the existence of informal mechanisms for pooling risk at the family or community level blurs the line between "protected" and "unprotected" work and must be integrated into the design of incentives in overall social protection programs.

However, informal mechanisms fail in the presence of covariate shocks: Local pooling of risk mitigates the moral hazard of national programs, but often fails in the presence of prolonged

\footnotetext{
${ }^{18}$ Gill, Indermit and Nadeem Ilahi (2000) “Economic Insecurity, Individual Behavior, and Social Policy” LCRCE/World Bank, unpublished manuscript. Guasch (1999) recommends a combined UI and individual savings account program where the ISA serves as a premium, and only once the ISA is depleted will a person collect UI

${ }^{19}$ Kugler, Adriana (2000) “Does Replacing Employer Insurance for Self-Insurance Improve the Performance of the Labor Market? The Case of the Colombian Severance Payments Savings Accounts” LCRCE/World Bank, unpublished manuscript.

${ }^{20}$ Cunningham, Wendy (2000) “Unemployment Insurance in Brazil: Unemployment Duration, Wages, and Sectoral Choice” LCRCE/World Bank, unpublished manuscript. Gonzaga (2003)

${ }^{21}$ Wodon, Quentin and C. Siaens (1999) “Training for the Urban Unemployed: A Reevaluation of Mexico’s Probecat” in World Bank (ed) Government Programs and Poverty in Mexico, Report No. 19214-ME.

${ }^{22}$ In available studies a decrease of income by 10 percent leads to a fall in consumption by only one to four percent. See World Bank (2001) Household Risk, Self-Insurance, and Coping Strategies in Urban Argentina, Report No. 22426-AR (World Bank: Washington, DC) for a review of the literature.

${ }^{23}$ See Fajnzylber, Maloney and Montes (2003) and Bosch and Maloney (2004)
} 
covariate shocks. For example, 80 percent of Argentines would turn to family, neighbors or friends if they became unemployed but only 40 percent would turn to this group in periods of wide-spread unemployment (World Bank 2001). ${ }^{24}$ The large fraction of workers delinked from formal institutions and the relative frequency of large covariate shocks has led the region to experiment with three mechanisms which vary in goals and which depend to differing degrees on existing institutions for targeting and the quality of administrative capacity. ${ }^{25}$ Workfare programs such as Trabajar in Argentina self target by putting wages below market thereby being attractive only to those without other options. The program was less successful in Colombia where legal barriers proscribe subminimum wages payments; instead greater effort was put into conditional transfer programs that relied on well established targeting systems and training programs. These tend to benefit the young and informal sector workers. Conditional cash transfer programs tweaked with counter cyclical triggering devices can help families smooth crises while defusing somewhat concerns about asitencialismo, but they require existing household poverty mappings for targeting which can be administratively complex and are less well suited to target those affected by employment shocks. Training programs for, particularly youth, combine cash infusion with human capital accumulation.

\section{Future Work ${ }^{26}$}

- Nature of unemployment shocks. A mapping of the probability, duration, and demographic distribution of employment shocks is, in theory, necessary to know whether systems should emphasize self insurance, as LAC has done, versus pooling risk through true UI as ECA has done.

- Quantification of effects on labor supply and remuneration. As a complement, more research is needed on the magnitude of the moral hazard issues in terms of reduced search and hence higher unemployment. The most common areas of UI research in the US and European literature is the employment disincentive effects (to a much lesser extent) measured by unemployment duration and (to an even lesser extent) the re-employment wage effect. For LAC economies, a third issue - sector of re-employment - is also a highly relevant issue.

- Formal, informal and non-standard safety nets. A better understanding of the efficacy of private safety nets is necessary so as not to crowd out mechanisms with good monitoring with public programs that are more subject to moral hazard. To the degree that informal mechanisms perform poorly, particularly during periods of highly covariate shocks, further exploration of alternate vehicles for channeling income support are necessary.

- Redistributional issues. Taking the social protection program as a whole, who pays and who benefits? A UI program financed by the VAT, for instance, is a transfer to the middle class from the general population.

\footnotetext{
24 This has big implications on who is eligible for the program; in Brazil, for example, only 40 percent of the labor force is eligible for UI, and less than 10 percent of the unemployed benefit from the UI program. De Ferranti, et. al. (2000)

${ }^{25}$ See De Ferranti et al (2000) “Securing our Future” as well as Maloney (2003) for a discussion of the design of emergency programs.

${ }^{26}$ See also Fiszbein (2004): Beyond Truncated Welfare States:Quo Vadis Latin America” for a think piece on this topic.
} 


\section{d. Non-monetary labor costs}

By non-monetary wage costs we understand all those costs over and above the (monetary) salary directly received by the worker: labor taxes, Social Security contributions, bonuses, vacations, training contributions, family allowances etc.

Non-monetary wage costs are paid by both firms and workers. . . Marrufo (2001), Cox-Edwards (2001), Gruber (1997), and Mondino and Montoya (2002) find that workers absorb a large fraction of non-monetary wage costs (estimates range from 50 to 90 percent) in Mexico, Chile (Cox Edwards and Gruber) and Argentina, respectively. Heckman and Pages (2002) find similar results for a set of Latin American countries.

... and may decrease employment and increase unemployment. Heckman and Pages find a robust negative effect of social security payments on employment and unemployment in a global sample, although the latter effect does not appear significant in the LAC sub-sample.

To the degree that labor taxes exceed benefits, they provide an incentive to become informal. Poor enforcement of regulation gives workers the opportunity to avoid paying labor taxes if they calculate that the benefits received in the formal sector fall short of those in the informal sector. Mexico and Chile have worked to align costs and benefits of their social security programs to decrease the disincentive to informality by setting up individual accounts for pensions or to encourage formality; the results have been modest. Clearly, such a realignment sharply limits the potential for using labor taxes for redistributive purposes. A small scale of operations and low and stagnant productivity hamper the ability of small firms to amortize these costs and pool workers' risks efficiently, leading many to noncompliance with labor laws even if they become formal in other dimensions.

. . . and may decrease productivity. Montes and Santamaría(2004) and Gracia and Santamaría (2004) show a negative relationship between non wage costs and TFP growth at a sectoral level for México and Colombia. Although, at the conceptual level the relationship between non-wage costs and productivity is not as clear as the one between firing costs and productivity, there exist some channels through which such costs may affect productivity growth. Paramount among these is the fact that high non-wage costs may prevent firms from growing and registering (i.e. be informal), again preventing them from achieving economies of scale and making more difficult access to some very important services accessible to formal firms, such as credit.

\section{Future Work}

- Magnitude of effects and interactions with other policies. A more precise estimate of the impacts of heavy non wage costs on labor demand and firms' growth potential and how these change when firms are unable to pass them on to workers, for instance, in the presence of a minimum wage, would be desirable.

- Links between benefits and taxes and the incentive to informality. On the supply side, a better understanding of how perceived misalignment of payments and benefits affects the decision of workers to be informal is needed. 


\section{e. Minimum Wages ${ }^{27}$}

Theoretically, the minimum wage offers a trade off between raising the incomes of poorer workers to provide a "living" wage and the possible negative employment effects that, taken as a group, may leave the poor potentially less well off.

Minimum wages affect the distribution of wages... especially in the informal sector. Despite concern about enforcement, kernel density plots suggest that the minimum wage is often binding and sometimes strongly, as in the case of Colombia. ${ }^{28}$ Both studies also confirm as a general rule in the region, the existence of what Neri and others term the "efeito farol" or lighthouse effect, that the minimum wage is more binding in the informal than the formal sector. This adds support to the idea that the informal sector is not completely unprotected by social norms, but in fact is covered by notions of fair wages.

Further, the wage is used as numeraire for wage gains throughout the distribution thus leveraging the effect even up to middle income workers. ${ }^{29}$ This contrasts with the OECD where only youth whose wages are clustered around the minimum wage are affected.

The minimum wage can be a tool for poverty and inequality reduction but it can be set too high and lead to greater income inequality. The recent LAC regional study "Minimum Wages: Employment, Wages and Poverty"30 commissioned studies of several countries and concluded that in countries with relatively low minimum wage levels, the minimum wage increases the wages of poorer workers, has minimal effects on unemployment, and leads to an aggregate net increase in household labor income for the poor households. It also reduces income inequality because the numeraire effects diminish to zero in higher earning households. ${ }^{31}$ However, in Colombia, a country with relatively high minimum wages, Arango (2003) finds that the lost employment effect dominated the wage effect and led to an increase increased poverty and an increase in household labor income inequality. Thus, while a high minimum wage may serve a social justice objective, by setting it "too high," it can have the opposite effect.

Further, the most "vulnerable" workers are the first to be hurt by excessively high minimum wages. Even where minimum wages are relatively low, the wages of young, low-skilled, and female workers benefit from a higher minimum wage - as do those of prime-aged, skilled, and male workers -, but the unemployment effects are also concentrated on them. Montenegro and Pages (2004) for example, find that, as with job security provisions, minimum wages reduce the employment probabilities of the young and unskilled. In essence, their income as a group is redistributed to less vulnerable segments of the labor force.

The unemployment effects imply a need to combine the minimum wage with other social welfare tools. While a well-targeted direct policy of tax and redistribute would most efficiently achieve the redistribution goals, the minimum wage may be a more realistic means for achieving this goal. It avoids many of the pitfalls of other social policies: self targeting, market (rather than government) income redistribution, minimal public administration, no perverse labor supply incentives (receipt of benefit is contingent on being in the labor force), and it does not ring of paternalism

\footnotetext{
${ }^{27}$ See background document by Cunningham.

${ }^{28}$ See Maloney and Nuñez (2004) Cunningham (2004). See also Gindling and Terrel for Costa Rica who nonetheless find no impact in the informal sector.

${ }^{29}$ See Maloney and Nunez (2004), Fajnzylber (2002), Cunningham et al (2004), Garcia Verdu (2003)..

${ }^{30}$ Cunningham (2004)

${ }^{31}$ See Cunningham, Neumark and Siga 2004 for Brazil, Maloney and Nunez(2004) for Colombia
} 
(asistencialismo) or political favoritism (clientelismo) as the beneficiaries are selected by the market. However, the unemployment impact on the most vulnerable workers suggests the importance, again, of taking an integrated view of social protection and to maintaining the complementarities of the various elements in mind. Raising wages to provide a decent standard of living for workers necessitates implementing some type of income security scheme for those who lose to guarantee that the target groups will experience a net benefit.

The minimum wage can be a severe barrier to macro economic adjustment. The US and European literature is inconclusive on this issue. However, the critical difference in how Mexico and Colombia adjusted to their relative recessions of the 1990s appears in mandated maintenance, and in fact increase, in the real value of the minimum wage during the crisis. This led not only to high and sustained levels of unemployment, but to a severe case of classic formal/informal dualism. ${ }^{32}$

Minimum wages are costly to public finances. Social expenditures are closely tied to the minimum wage, so any increase in the minimum wage also has large implications for the public deficit. The largest expenditure categories that are affected is the public sector wage bill, where a 10 percent increase in the minimum wage would increase total government expenditure by 1.4 percent in Panama, for example, and the pension system, where, for example, a 10 percent increase in the minimum wage in Brazil would increase pension payouts by 3.3 times more than the increase in receipts. In addition, other social benefits ranging from salary bonuses to job training stipends to "shock benefits" (death in the family, birth, marriage, etc.) are denominated in minimum wages, and eligibility for social programs are tied to it.

Careful thought should be given to structure minimum wage institutions for it to be an effective policy tool. Its objectives should be kept narrow and the expectations of its ability to resolve social inequity kept modest. Changes in minimum wages should be informed by the evolution of labor productivity. A simple structure is easier to enforce and attempting to address all segments of the workforce generally fails. Both facilitate enforcement. The impact on the fiscal position is important and, as inflation falls, its enhanced role as a key nominal rigidity that exacerbates other labor market distortions rises.

\section{Further work}

- Identification of the "right" minimum wage. The minimum wage regional study documented one country where the minimum wage reduced poverty by benefiting the poorest (Mexico), and two countries with higher minimum wages where the impact was neutral or even detrimental to the poor. Thus, the question remains, what is the "correct" level of the minimum wage such that it is high enough to maximize benefits for the poor, without tipping the balance such that it benefits other groups to the detriment of the poor. More country studies, with varying levels of the minimum would allow for a more complete picture.

- Who benefits from minimum wage increases. Contrary to the US and Western Europe, where the minimum is mostly collected by youth, in LAC primary workers are also minimum wage earners and to date there is poor understanding of the overall profile of the minimum wage earner and hence the types of complementary social safety nets that are necessary.

\footnotetext{
${ }^{32}$ See Fiess, Fugazza and Maloney (2003).
} 


\section{f. Unions ${ }^{33}$}

Unions differ greatly in character throughout Latin America, but commonalities emerge in their impacts on: the profitability of the firms, investment and technology, wage and employment determination, and the size of the unregulated informal labor market in Latin America.

Unions decrease firm profitability: Several studies for Latin American countries are consistent with the OECD literature that in advanced countries union power tends to harm business profitability. Saavedra and Torero (2002) show decreasing profitability for firms in the presence of unions for Peru during the period 1994-1996 Similar evidence if found for Brazil by Menezes-Filho, Zylberstajn, Chahad and Pazello (2002) where they use the Annual Industry Survey pooled for the period 1988-1998. However, the results become inconclusive when observing the performance over time. Cassoni, Labadie and Fachola (2002) present preliminary evidence of a negative impact of unionization in profitability for Uruguay, though they acknowledge further work needs to be done. Urizar and Lee (2003) argue that in spite of low union density, productivity in coffee producers firms in Guatemala suffer greatly in the presence of Unions.

The impact on aggregate employment is unclear, but there is evidence of efficient bargaining. The mainstream "efficient bargaining" models stress how in the presence of firm monopoly power, unions may choose to direct their negotiated share of rents toward either higher wages or employment. Hence, their impact_on total employment may differ from standard "right to manage" models where unions raise wages and firms move along the demand curve to reduce employment. Maloney and Ribeiro (2001) find a strong impact on employment in Mexico, but little on wages, consistent with an extreme "efficient bargaining" model. Both Saba Arbache (2002) and MenezesFilho et al (2002) find wage effects, and the latter work finds positive employment effects of unions as well. Menezes also finds a concave relationships where some union concentration raises both wages and salaries, consistent with efficient bargaining, but after a point leads to deleterious employment effects. In Uruguay, Cassoni, Labadie and Fachola (2002) also find that unionization promotes both higher wages and higher levels of employment. ${ }^{34}$ Though suggesting that unions may increase employment in their host firm, the firm level analyses cannot capture economy wide effects. Some labor codes, for instance, dictate that negotiated contracts cover all firms regardless of size, and are widely seen as imposing inflexibility and hardship on smaller firms.

More importantly, unions may pose a barrier to technological adoption although the empirical work to date is only suggestive. The theoretical literature does not unambiguous conclude how unions impact innovation. Hjalmaarson (1990) suggests that Swedish unions understand the link between technological upgrading and wages increases and aggressively encourage firms to adopt new techniques. Parente and Prescott (2000) argue that more commonly unions focus on the short term goal of protecting jobs at a great cost in foregone productivity gains. US studies find consistently negative impacts of unions on R\&D but this is not so clear for European countries, which seem to bargain more on employment rather than wages. To date, there is little evidence for Latin America on which to report. One of the few examples is Reis and Crespo (2004) who, using information for 1600 firms in Brazil, find evidence that labor legislations restrict firms to hire relatively more skilled workers which may, in fact, push toward more technological adoption. On the other hand, a case study of the aviation sector by Garcia Verdu (2004) suggests negative impact of

\footnotetext{
33 See Background paper by Bosch and Siga 2004

34 They argue, somewhat counter-intuitively, however, that the channel through which these changes occur is substitution of labor by capital.
} 
union job protection actions on technological upgrading equipment which then permit potential productivity gains.

... and to maintaining the quality of public services, such as education. A recent literature stresses how public sector unions may impede the necessary upgrading of public services. Alejandro Foxley (2004), Finance minister under the first democratic government of Chile, sees union efforts to prevent measuring educational quality and their resistance to reform as the largest barrier to the further reduction of poverty in Chile. Similar accounts are found in Mexico (Washington Post on 7/14/2004) where education unions are seen as corrupt vehicles for patronage that block even basic quality standards, such as requiring that teachers show up for class. Similarly, Mexican public sector unions are the main obstacle to reforming the financially unsustainable public pension system. In Argentina, Murillo et al find indirect evidence of a negative effect of teacher's unions on student performance coming through excessive emphasis on job stability and increased conflict. Zegara and Ravina (2003) find no similar impact either way of unionization in Peru. Given the central role of education in both poverty reduction and technological advancement, this is a central, and under researched, element of union influence in the developing world. The implications for poverty reduction and country innovative capacity are almost axiomatic.

The evidence on the impact on informality is thin: If the rents from efficient bargaining are channeled into more formal employment and only to a lesser degree toward higher wages, as appears to be the case in several countries, then we might expect few deleterious impacts on the levels of formality. On the other hand, to the degree that firms subcontract to the sector to avoid union power, a subject on which there is virtually no research, we could expect increasing informality. Recent empirical evidence provided by Galli and Kucera (2004) for a sample of 14 Latin American countries suggest that countries with higher "civic rights," including the right to free association, collective representation and free expression of grievances, develop higher shares of formal employment, arguing that the positive effects of civic rights more than offset any negative effect due to market segmentation.

\section{Further work:}

- Technological Progress. How much do unions really obstruct technological adoption?

- Public sector quality. To date, there is insufficient data to evaluate school performance (Ornelas 2004) or to document the channels, for instance resistance to curriculum changes or teacher evaluations or discipline, which may impede progress.

- Centralized v. decentralized Unions. As pointed out by Carneiro et al. (2001), there is a literature that argues that the extremes of collective bargaining are best. Either wages are set centrally and coordinated by the three parts involved (government, private sector, and unions) or at a firm level. The worst case, allegedly, is when there is no national level coordination, but all firms within an industry are bound by agreements perhaps inappropriate to them. Mexico seems to provide a case where the centralized bargaining was able to reduce inflation and coordinate a big fall in wages during the crisis that allowed it to recover fast, but until the present no work has been conducted in this direction. 


\section{g. Worker Training ${ }^{35}$}

Worker training is a right in many countries. Ongoing upgrading of the work force through training, particularly in rapidly evolving industries, is a central element of the national innovation system.

Training tends to have a positive impact on productivity. . . In general, the available rigorous empirical evaluations of training programs find that training increases firm-level productivity, (Tan and Lopez-Acevedo, 2003; Barrera and Higuera, 2004 among others for LAC). The impact on subsequent earnings is less clear, the productivity increases can translate into higher wage premiums but especially for skilled workers. Firm investments in training tend to pay off particularly when training takes place in-house and benefits already skilled workers. Further, it has been found that increased continuity of training leads to larger impact on productivity than does intermittent training.

...and is complementary to firm $R \& D$ and technology adoption. Firm-level data show that firms that are capital intensive and/or invest in R\&D and technological change are more likely to train workers (Barrera and Higuera, 2004; Gill, Dar, and Fluitman, 1998, and Tan and Batra, 1995b and 1997).

Larger firms are more likely to provide training in the Caribbean, Colombia, Mexico, and LAC in general. $^{36}$ Small firms may be more constrained by resources, lack knowledge about training benefits, invest less and have higher labor turnover rates than large firms (De Ferranti, 2003). Some evidence from Mexico suggests that membership of a union raises the likelihood of receiving training (Lopez Acevedo 2002).

Training is not a substitute for good schools. Firms overwhelmingly choose to train skilled (secondary education or above) workers. This is an exceptionally robust finding that is salient in cross-country household surveys, administrative databases, and firm panel data sets. Although the likelihood of training increases with all levels of education, the critical threshold seems to be completion of secondary education.. This most likely reflects the idea that investment in training requires a sufficient prior skill base in order to pay-off. This pattern is consistent with the pattern of returns to training. Overall, firms rarely invest into basic skills of a worker, rather focusing on specific job related skills.

The efficacy of training differs by provider and modality. Studies of programs in Mexico find that on-the-job training in Mexico is more effective than classroom training. Further, private training centers seem to out-perform public training centers in the Caribbean, Colombia and Brazil (McArdler and Blom, forthcoming, Barrera and Higuera, 2004 and World Bank, 2004).

The majority of firms in the LAC region receive training from private providers. In the LAC region, only $16 \%$ of enterprises use public institutes for external training (Batra, 2001b). Private sector providers - firms themselves, industry associations, buyers and equipment suppliers, and private training institutes and colleges - are more important than government-run training institutions as sources of training. Naturally, there exists a large variation within the region. In Chile and Uruguay, employers rely mostly on private external training sources, whereas firms in other countries, such as Belize, Ecuador, Nicaragua, and Trinidad and Tobago, involve public training suppliers to a larger extent (Marquez, 2002; Cinterfor 2001, and De Ferranti et al., 2003). In almost

\footnotetext{
35 See background note by Andreas Blom and Gladys López-Acevedo

${ }^{36}$ Gill, Dar, and Fluitman (1998) and Tan and Batra (1995b), McArdler and Blom (forthcoming) and Marquez (2002)
} 
all countries, the private firm training is not formally recognized by the public training and education system. Thus reducing the worker's incentive for training.

The public training programs in Latin America and the Caribbean differ substantially in design. In all countries of the region, training programs derive their financing from payroll levies earmarked for the purpose which varies from less than 0.5 percent to 3 percent of the payroll. Beyond this, there is great variety in design. In Chile, training is publicly stimulated through incentive programs to private providers; in Brazil, a tri-partite organization organizes training through a mix of public and private providers. In Colombia and Jamaica, apex organizations administer, regulate and provide training for the work force via large public training institutes with limited private sector linkages. Recently, the movement is away from public provision which is often seen as huge an ineffectual, towards incentive based programs relying on non-governmental providers for training. This implies (i) a decentralization of the training decisions to the company, and (ii) a separation of financing of training from provision of training.

\section{Further Work}

- More rigorous evaluations of training programs in the region. Most evaluations are based on descriptive data with little or no control of other relevant variables. Good practices of impact evaluations and, in particular, policies to foment a culture of monitoring and evaluation of training program would be of high value (examples of evalutions of youth training programs can be found for Chile’s Chile Joven (Aedo, 2002) and Peru's Projoven (Nopo et.al. 2003))

- Training for poorly educated workers. Since training is focused on workers with secondary education or above, it is not clear what to do with school dropouts that lack the basic skills to "be trainable" from a firm perspective. Research into successful training programs of low-skilled youth and the appropriate modes of delivery and financing would be valuable. Further, should scarce public financing be devoted either to induce firm training of skilled workers with a proven return, or to finance training for unskilled workers with a shown lower return?. There might be also a role for targeted adult education programs, especially in countries with high illiteracy of the labor force, considering not only the potential direct earnings impacts but also the effects on children's schooling attainment.

- Optimal goverment intervention in training systems. If implemented, the above recommendations of separation of finance and provision would imply an unregulated private market with a public subsidy. It's not clear whether this would be sufficient or whether there a new role for public training commissions/regulators to (i) certify private providers of training; (ii) build so-called lifelong learning/competency systems; (iii) subsidize technical assistance to SMEs for developing of HR strategies; and (iv) other responsibilities. A number of LAC countries, notably Chile, Mexico, Colombia, and Jamaica are currently pursuing at least one of the above possibilities.

- Moving forward reforms While few policymakers doubt the direction of change, there has been strong opposition to reform, since (i) the beneficiaries of public training programs rarely see the costs of training programs and the programs therefore enjoy popular support, and (ii) the employees of the training institutions have vested interests. This has implied frequent and unproductive backtracking of reforms in a number of LAC countries, most notably Colombia, while in many others reforms are not being even discussed. Research into the relationship between the extent of reforms (public provision v. public incentive programs for private training) and the impact would be valuable. Further, what are the critical elements of a reform of public training institutions that makes a reform palatable for all stakeholders? 


\section{The political economy of Labor Market Regulation Reform}

The general conclusion, as Heckman and Pages(2004) stress is that labor regulation does matter although at present the empirics are largely restricted to identifying the sign and significance of the effect. A major outstanding agenda, then, is to identify more precisely how important these effects really are. In some cases, such as Colombia, the tight coincidence of the perverse behavior of the minimum wage during the crisis with the rise in unemployment and informality suggests that the impacts can be very large. On the other hand, it is less clear still how much of a gain in employment or formalization might be gained with reforms of other institutions.

Yet labor market reform is the area where the region has been less intrepid. Even when policymakers are upbeat they fear that strong opposition to reform from unions and public opinion is not worth spending their often limited political capital. Businesses themselves tend to adopt a view narrowly focused on flexibilization, and key potential beneficiaries are often unorganized to participate productively. Weak and over stretched Labor Ministries are often uncapable of leading the complex process of dialogue and communication needed to make reforms feasible and assume the more complex oversight role that reforms might entail. A better understanding of the critical elements to make reforms attractive for all stakeholders is needed. The political economy may be facilitated by capitalizing on synergies of advancing multiple reforms, for example investment climate reforms, to the extent that addressing other (first order) constraints to job creation may ease job loss concerns.

\section{Equity and poverty}

\section{a. Poverty and inequality ${ }^{37}$}

The labor market is perhaps the central conduit from growth to household poverty and inequality. Labor earnings count for over $70 \%$ of total household income in most LAC countries. Urban labor markets, in particular, are taking a more prominent role with migration and shrinking of the agricultural sector. Across the 1990s, the hourly earnings distribution became more unequal in Argentina, Bolivia, Colombia, Nicaragua, Peru, Uruguay and Venezuela although in the rest of the region changes were very small or, in the case of the largest market, Brazil, the distribution improved. These earning movements do not necessarily translate into changes in household income inequality. Velez (2003) for example, finds that the increasing wage dispersion was offset by an increase in female labor participation among poor households.

Labor institutions can influence the distribution of income and poverty. As discussed in the previous section, minimum wages are very binding among informal workers and less frequently but sometimes very significantly among the formal at relatively high levels of income. And, as noted earlier, the union impact may be mixed either because they put little pressure on wages, or because of non-linearities in the impact of union power, or, as in the odd case of Brazil, union power appears correlated with higher dispersion. Taking an aggregate view, Calderon, Chong and Valdes (2004), using a panel of 121 countries from 1970-2000 argue that de jure regulations seem to have no impact on income distribution, but de facto regulations do weakly. Partially confirming the results above, they find that minimum wages worsen income inequality, while trade membership improves, government employment, and mandated benefits - proxied by maternity leave - reduce income inequality. Ratification of the ILO convention 87 and social security contributions do not have a robust impact.

Overly protective labor regulations may prevent micro firms from growing: By tilting the costbenefit ratio of firms and workers towards informality, poorly designed legislation may discourage

\footnotetext{
${ }^{37}$ See background paper by Arias and Diaz (2004)
} 
micro and small enterprises from capitalizing the productivity gains that come with scale economies and innovation. If, as discussed above, micro firms undertake a cost-benefit analysis of engaging in formality, extraordinarily high registration costs that are endemic to the region (Janson and Chalmers 2001), or heavy labor taxes may create a poverty trap: due to low productivity firms cannot afford to comply with business and labor regulations, and informality in turn constrains economies of scale and productivity growth..

However, the bulk of earnings differentials and thus poverty and income inequality in LAC is not generated by the labor market but largely reflects the productivity levels and differences in workers' endowments. Labor markets do not seem to operate with pervasive segmentation. The residual earnings disparities associated with gender, ethnicity, race, informality (micro-firms and self employed), occupation, sector of employment, and geographic location are of second order and their reduction would have a larger impact on inequality than on poverty, which is symptomatic of overall low labor productivity. Labor reforms to date have indeterminate effects. As Saavedra (2003) notes, the effects of changes on labor market outcomes in the region have been modest partly because of the simultaneous imposition of reforms with offsetting effects.

But the explanations for observed changes in inequality are probably to be found elsewhere, namely through general reforms undertaken. Behrman, Birdsall and Szekely (2003) found that financial reform, capital account liberalization and tax reform have contributed to increased earnings inequality, while privatization was a force towards equalization. The reforms worsened inequality in the short-run, but this effect tended to fade away over time.

Or skill biased technical change. As been found elsewhere in the literature, Behrman et. al's estimates suggest that trade openness had no effects whatsoever on inequality, instead they suggest that skill biased technological progress (SBTC) rather than trade per se has been the mechanism through which the reforms have been operating. Sánchez-Páramo and Schady (2003) reached a similar conclusion using repeated cross-section data for Argentina, Brazil, Chile, Colombia, and Mexico. In particular they suggest that even though the direct effect of trade liberalization on earnings inequality may be small, trade is an important source of technology transmission. However IADB (2004) argue that even when many economic sectors in LA countries have acquired new technologies after the period of trade and financial liberalization, changes in technology are far from being the unique source behind the trend in earnings differentials. In particular, trends in gender earnings gaps and the evolution of earnings for high-tech workers (such as engineers and computer science graduates) are difficult to reconcile with predictions from any version of the SBTC hypothesis. Moreover, some care must be taken in interpreting the results on the rising average returns to higher education and their relationship to relative demand shifts. While these demand shifts are likely to play a key role in rising earnings inequality, the observed upward trends can also reflect partially the upgrading of the unobservable skills of the labor force.

The unequalizing role of unmeasured workers characteristics Most of the disparity in wages cannot be generally explained by observed characteristics. Increasing evidence based on quantile regressions indicates the existence of unobserved wage heterogeneity among individuals with the same education, sector of work (formal/informal), gender, age and experience. Factors such as the quality of education, family background, individual ability, and labor market connections are distributed unevenly across workers. These unobserved (by the analyst) characteristics may grant an advantage in access to high paying jobs, affecting both human capital accumulation decisions and its returns in the labor market. In particular, numerous studies for LAC and developed countries point that returns to schooling increase along the earnings distribution so that for example the high return to college is not available to all workers alike. ${ }^{38}$ There is also evidence that other earnings gaps

\footnotetext{
${ }^{38}$ See Arias and Diaz (2004) for references to these studies.
} 
including gender, race and sector of employment vary in a meaningful way for workers at different points of the conditional earnings distributions. The contribution of this "within" group earnings inequality to total inequality and the potential role of public policies, including labor market interventions, has not received sufficient attention in the policy discussions.

\section{Further Work}

- The role of unobserved wage determinants More work needs to be done to understand the role of unobserved determinants of earnings such as deficiencies in early-childhood development, education quality and labor market connections that would signal incentives for skill investments, ensure completion of full courses of basic education, and allow for transitions to higher education thus leveling the initial playing field and reducing the wage disparities.

- Identification of possible poverty traps Labor market signals and feedback effects to human capital accumulation through the pricing of labor (earnings returns), barriers to micro firms accessing public services broadly defined, the impact of unions, and other labor protections on educational or health services deserve greater attention as potential sources of poverty traps.

- Indirect links to distribution What other factors besides SBTC may be driving the observed increase in earnings gaps and how do existing institutions interact with these factors and agents' responses to them

\section{b. Women in the labor market ${ }^{39}$}

Labor Force Participation trends are converging. Over the last 40 years, women's labor force participation has increased in all countries in Latin America and the Caribbean, while men's has decreased. The proportion of working adult women ranged from 12 percent (Dominican Republic) to 54 percent (Jamaica) in 1960 and by 2000, the range was between 37 percent (Peru) and 74 percent (Jamaica). Men's participation, on the other hand, declined from approximately 92 percent across the region to 85 percent by the end of the century. Not surprisingly, women's share of the labor force also increased over this period, from approximately 20 percent of the labor force to onethird of all workers.

Women's participation is driven by education, urbanization and late marriage: The diverging trends are due to several factors that differ by gender. First, educational attainment has increased in the region (World Development Indicators) leading to higher human capital for women, and thus labor force entry among those whose value was previously higher in the home (Blau 1998), but a decrease in male labor force participation as boys spend more time in school rather than entering the labor market. Over this period, the growth in women's education attainment exceeded that of men, and in some urban centers in Latin America, women's stock of education, particularly that of young women, exceeds that of men. Second, rapid urbanization has lead to a formalization of the work relationship so women, who are often invisible workers in rural family businesses, became visible employees in the cities. Third, women are marrying later, and thus must work to support themselves (Demographic and Health Surveys). Finally, the emergence of frequent economic shocks and unemployment in the region has increased the need for female labor to cushion the household from negative income shocks (Geldstein 2000, World Bank 2000, Cunningham 2000).

${ }^{39}$ See background work by Cunningham (2003) 
Female unemployment rates are above those of males in all countries in Latin America This reflects a world-wide trend which the US and European literature suggests is due to women's role as secondary earner in the household that permits for longer spells of unemployment, the difficulty in finding employment that allows for the competing demands on women's time, and women's frequent entry and exit from the labor force, resulting in more frequent unemployment spells and their lower attachment to it, leading to longer search periods (Blau and Ferber, 1992).

While women participate less in the labor market than men, their labor in the household far exceeds that of men. Homecare is more than a full time job for women who do not work outside the household (49 hours weekly among married Mexican women, for example) while it is a substantial part time job for those who do (33 hours weekly). Men, on the other hand, spend approximately 5 hours weekly in housework, regardless of own, or spouse's employment status (Cunningham and Jacobsen 2004).

Women are disproportionately informal. While women generally make up approximately onethird of the LAC labor force, they account for approximately half of all informal wage jobs, are over-represented in the self employment sector and are underrepresented in the formal sector (Cunningham 2001). Further, Markov transition matrices suggest women have exaggerated rates of transition between self employment and being out of the labor force (Bosch and Maloney 2004).

But this seems largely a result of balancing home and work responsibilities: A body of sociological work (Geldstein 2000, Chant 1991, Gonzalez de Rocha 1994), supported by survey data shows that women have a higher preference for unstructured work environments and shifts than men. Women disproportionately cite "the need to care for the household" as their reason for being self employed, contract workers, or informal wage earners; where the flexible work shifts and work locations allow them to more easily fulfill their gender roles as primary caregivers of the households (Cunningham and Gomez 2004). Further, informal work also permits the easy and relatively frequent entry and exit from the labor market, which is characteristic of women's labor histories. Partly due to household responsibilities, partly due to their role as safety nets when the household experiences a negative income shock (Cunningham 2001, World Bank 2001), female turnover is much higher than men's.

This view of largely home responsibility-induced informality is borne out when the patterns of single and married women are broken out. Unmarried women without children, who have few domestic responsibilities are even more represented in the formal sector than are men while married women are over-represented in the unpaid labor sector. ${ }^{40}$ Men's sector of employment does not differ by marital or parental status suggesting the importance of child care responsibilities (Cunningham 2001). Further, single, childless women's transition matrices are statistically indistinguishable from those of men. This said, employers also know female turnover patterns, and may discriminate for statistical reasons against young women in filling formal jobs. In some countries (eg., Bolivia), labor regulations still contain provisions such as a shorter work week, prohibition of night work, weak regulations of domestic work and maternity benefits paid by employers and non-transferable to husbands, all of which hinder better quality employment for women.

Occupational segregation by gender remains a defining characteristics of Latin American labor markets. The Duncan index (proportion of men and women who would have to trade occupations to

\footnotetext{
${ }^{40}$ In Mexico, for example, 10 percent of married women are unpaid workers while 87 percent of unmarried women are formal sector employees.
} 
create gender equality) is approximately 35 percent in the region, and even higher when using 3-digit occupational codes. Women are over-represented in the service and managerial occupations while men dominate in manufacturing and professional fields (Cunningham and Jacobsen 2004). Occupational choice may be due to discrimination at some time over the life cycle, or based on family decision and competing time demands in future life.

Men earn more than women, but the wage gap is rapidly shrinking: By 1997, women's median hourly wage was higher than men's in Argentina and Costa Rica, and was 90 percent of men's hourly wage in several other countries. While monthly wage gaps show a larger gap, it is important to note that women work approximately $1 / 3$ fewer hours per month as men. Very little of the wage gap can be attributed to differences in observable characteristics. Working women and men are approximately the same age and have similar levels of education. Instead, the wage gap is almost fully due to unobservable characteristics, which may include everything from discrimination (Oaxaca 1973) to incentives created by legislation (Haro, unpublished) to self selection (Akerlof and Kranton 2000) to occupational preferences (Cunningham and Jacobsen 2004) to unobserved differences in job experience (Blau 1998) to "personal choices made outside the work environment" (Furchtott-Roth and Stolbs 1999). Blom and Azevedo find no evidence of differences in training received by gender in any occupation. There is evidence of potential greater pay discrimination at the higher salary jobs at any given skill level. Montenegro (2001) shows that in Chile the gap increases as women move up along the earnings distribution, going from 10 percent in the bottom part of the distribution to about 40 percent in upper part.

Future Work: Potential areas for future work in understanding the importance of gender in the labor market include:

- Identifying the sources of the unobserved portion of wage gaps. To improve wage equity, particularly as education attainment rates converge, it is necessary to better understand those factors that cause persistent wage gaps. Labor market data that are commonly collected are not sufficient, since they do not include information on the most likely causes of the observed gap: differences in actual, as opposed the generally measured potential level of labor market experience, differential accumulation of human capital due to differential school experiences, the role of household responsibilities, occupational choice decisions, labor turnover, differential preferences by gender, skill obsolescence and employer preferences, to name a few.

- The role of the informal sector. The differential participation rates in these sectors begs the question of whether the attractive characteristics of informal sector work for women can be (or need be) replicated in the monitored and more protected formal sector. This requires a better understanding of the motivation for informal sector work - an area that sociologists have much to teach economists

- Labor legislation. There is virtually no discussion of the incentives created for employees and employers via labor legislation. However, anecdotal evidence suggests that sex-specific labor legislation actually creates incentives to discriminate against women (with parallel, but much fewer, distortions for men). A more careful consideration of the laws in order to even the cost between male and female workers, could improve equity in labor markets. 


\section{c. Race and Ethnicity}

Numerous studies have found important differences in conditional average earnings among different racial and ethnic groups. Hall and Patrinos (2004), using Oaxaca-Blinder decompositions find unexplained earning gaps of between 26 and 60\% for males in Bolivia, Ecuador, Guatemala Mexico and Peru in a comprehensive study discussing diverse aspects of inequality (income, education, health, etc.). Cunningham and Jacobsen (2003) find similar estimates between ethnic groups and Brazil's racial groups, but nearly no difference between Guyana's racial groups. Nopo, Saavedra and Torero (2004) find that after controlling for a large set of characteristics, there are racially related earnings differentials among wage earners favoring predominantly non-indigenous individuals in Peru. In this and other studies clear -but not well understood- differences in occupational structures arise. Similar to gender there is evidence of potential greater pay discrimination for workers at the best paid jobs within any skills set. For instance, Arias, Yamada and Tejerina (2004) find that in Brazil while the labor market rewards the educational investments of pardos similar to those of white workers located at the top of the adjusted wage scale, pardos at the bottom are rewarded similar to pretos. Nonetheless, at present, no consensus has been reached on whether these differences are mainly due to other unmeasured productivity factors historical characteristics or to what degree this is part of a consistent discriminatory pattern preventing minorities to access a better status. ${ }^{41}$

Cunningham and Jacobsen (2003) De Ferranti et al. (2003) devote a chapter to understand race and gender differences dividing the sample in white/non-indigenous male, white/non-indigenous female, indigenous male, and indigenous female. Using a methodology developed by Bourguignon et al. (2002) they simulate earnings of the "disadvantaged" group as if they were treated as the "advantaged" group and conclude that, although, there are between group disparities, within group variance explains most of the overall inequality observed. Moreover, Arias, Yamada and Tejerina (2004) find that the earnings gaps associated to skin color in Brazil are of second order after accounting for racial differences in family background and education quality. This has a strong policy implication since it is feasible that just targeting poor people might be the best way to reduce indigenous- non-indigenous gap. Still, a better understanding of the extent and mechanism of discrimination and other factors behind wage differences is needed.

\section{Future Work}

- Unpack the "unexplained component" of Oaxaca-Blinder decompositions. Parallel to the suggested future work for gender, little is known about the factors behind half of the wage gap between ethnic and some racial groups. Also, why is a wage gap not identified between racial groups in some countries? However, the ethnic and racial work has an additional dimension, which is better understanding how to identify and define the ethnically and/or racially diverse populations, which would allow for such analysis.

- Conduct experimental research to document discrimination: Methods analogous to those in the US which submit resumes differing only in racial background offer alternative measures of true discrimination (Handbook of Labor Economics 2001). More study of the ways institutions may be exclusionary, even if not discriminatory per se is also a priority.

\footnotetext{
${ }^{41}$ The problem as in many others based on Oaxaca decomposition, is that the residual is capturing any number of factors that might lead to differing wages (Altonji and Blank 1999). Another shortcoming of many studies is that they use mother tongue as proxy
} 
- Labor legislation: Many countries have enacted laws that prohibit racial discrimination in the labor market. However, little is know about adequacy, enforcement and effectiveness of this legislation.

\section{References:}

Addison, J. and J. L. Grosso. (1996). "Job Security Provisions and Employment: Revised Estimates." Industrial Relations. 35(4).

Addison, J. and P. Teixeira. (2001). "The Economics of Employment Protection." IZA Discussion Paper No. 381. Institute for the Study of Labor, Bonn, Germany.

Addison, J. T., P. Teixeira, and J. L. Grosso. (2000). "The Effect of Dismissals Protection on Employment: More on a Vexed Theme." Southern Economic Journal 67(1): 105-122.

Akerlof, G. and R. Kranton (2000). “Economics and Identity” Quarterly Journal of Economics 115(3): 715-53.

Arbache, J. S.. (2002). "Unions and the Labor Market in Brazil". Background paper for the Brazil Jobs Report. The World Bank and Instituto de Pesquisa Econômica Aplicada.

Arias, O. and W. Sosa. (2004). "Subjective poverty in Bolivia: a binary quantile regression approach, 2003." Work in process. World Bank, Washington, D.C.

Arias, O., Yamada, G. and L. Tejerina (2004). "Education, Family Background and Racial Earnings Inequality in Brazil.” International Journal of Manpower, Vol. 25, No. 314.

Barrera, F. and L. Higuera. (2004). "Characterization of Training in Colombia Household and Firms surveys”, Background study for a World Bank study “Colombia Lifelong Learning”, Bogota, Colombia.

Batra, G. (2001). "Skills Upgrading and Competitiveness in Developing Countries.” Labor Market Policies Course, April 23 - May 4. Washington DC: The World Bank.

Behrman, J., N. Birdsall and M. Székely. (2003). “Aid policies and Growth" in Latin America. Center for Global Development.Working Paper (U.S.); No. 29.

Bentolila, S. and A. Ichino. (2000) “Are Job Losses less painful near the Mediterranean?” CEPR discussion paper 2539. Oxford university.

Blanchard, O. (1998). "Thinking about Unemployment" Manuscript. Department of Economics, MIT.

Blanchard, O. and A. Landier. (2001). "The Perverse Effects of Partial Labor Market Reform: Fixed Duration Contracts in France." NBER Working Paper 8219. NBER, Cambridge, MA

Blau, F. and M. Ferber. (1992). The Economics of Women, Men, and Work, Second edition PrenticeHall, New Jersey.

Blau, F. (1998). “Trends in the Well-Being of American Women, 1970-1995” Journal of Economic Literature (23:1), 112-165.

Bosch, M. and W. Maloney. (2004). " Comparative Labor Markets Analysis Using Continuous Time Markov Processes." Work in progress. World Bank, Washington, D.C.

Bosch, M. and L. Siga. (2004). "Surveying the Effects of Unions in Latin America" Work in progress. Workd Bank, Washington, D.C. 
Calderon, C., A. Chong and R. Valdes. (2004). "Labor Market Regulations and Income Inequality: Evidence for a Panel of Countries.” WP514, IADB.

Capelli, P. (2000). Examining the Incidence of Downsizing and Its Effects on Establishment Performance. in D.Neumark (ed.), On the Job, New York : Russell Sage Foundation.

Cassoni, A., G. J. Labadie and G. Fachola. (2002). "The Economic Effect of Unions in Latin America: Their Impact on Wages and the Economic Performance f Firms in Uruguay.” Working Paper R-466. Inter American Development Bank, Washington, D.C.

Chant, S. (1991) Women and Survival in Mexican Cities (Manchester University Press: Manchester)

Cinterfor and International Labor Organization. (2001). "Modernization in Vocational Education and Training in the Latin American and the Caribbean Region”, Montevideo, Uruguay

Cortez Reis, M. And A. R. Vianna Crespo. (2004). “The Impact of Brazilian Labor

Cunningham, W. (2000) "Breadwinner versus Caregiver.” In Elizabeth Katz and Maria Correia (eds.) The Economics of Gender in Mexico: Work, Family, State, and Market (World Bank: Washington, DC).

Cunningham, W. (2001) Sectoral Allocation by Gender of Latin American Workers over the Liberalization Period of the 1990s, Policy Research Working Paper 2742 (World Bank: Washington, DC).

Cunningham, W. (unpublished) "Mexican Female Small Firm Ownership: Motivations, Returns, and Gender,” LCSPG/World Bank.

Cunningham, W. and Carlos Ramos Gomez (2004) The Home as the Factory Floor: Employment and Remuneration of Home-based Workers. Policy Research Working Paper No. 3295 (World Bank: Washington, DC).

Cunningham, W. and J. Jacobsen (2004) "Group-Based Inequalities: the Roles of Race, Ethnicity, and Gender" in David DeFerranti, Guillermo Perry, Francisco Ferreira, and Michael Walton (eds) Inequality in Latin America: Breaking with History? (World Bank: Washington, DC)

Cunningham, W. and W. Maloney (2003) “Heterogeneity among Mexico’s Microenterprises: An Application of Factor and Cluster Analysis” Economic Development and Cultural Change (50:1), 131-156.

Cunningham, W., D. Neumark and L. Siga. (2004). "The Effects of Minimum Wages in Brazil on the Distribution of Family Incomes:1996-2001." World Bank, Washington, D.C.

De Ferranti, D., G. E. Perry, I. S. Gill, and L. Servén. (2000). "Securing Our Future in a Global Economy." Latin American and Caribbean Studies Series. World Bank, Washington, D.C.

De Ferranti, D., et al. (2003). Closing the Gap in Education and Technology. Washington, DC: The World Bank.

Elmeskov, J., J.P. Martin and S. Scarpetta. Forthcoming. "Key Lessons for Labour Market Reforms: Evidence from OECD Countries' Experience". Swedish Economic Policy Review

Fajnzylber, P and W.F. Maloney (forthcoming), "Labor Reform and Trade Elasticities in Latin America.” Journal of International Economics.

Feenstra, R. C. and G. Hanson. (1996). "Globalization, Outsourcing, and Wage Inequality." Working Paper No. 5424.. NBER. Cambridge, MA. 
Fiess, N., M. Fugazza and W. Maloney. (2003). "Exchange Rate Appreciation, Labor Market Rigidities, and Informality." Policy Research Working Paper 2771. World Bank, Washington, D.C.

Fiszbein, A. (2004) "Beyond Truncated Welfare States: Quo Vadis Latin America, note, LCRSP, The World Bank.

Freeman, R. B. (2001). "Institutional Differences and Economic Performance among OECD Countries." Paper presented at the Bank of Portugal Conference Labor Market Institutions and Economic Outcomes. Cascais, Portugal.

Foxley, A.. (2004). “Successes and Failures in Poverty Eradication: Chile.” Mimeographed. ???

Furchtott-Roth, D. and C. Stolbs (1999) Women's Figures: An Illustrated Guide to the Economic Progress of Women in America. (AEI: Washington, DC).

Galli, R. and D. Kucera. (2004). "Labor Standards and Informal Employment in Latin America." Journal of Development Economics 32-5: 809-828.

Garcia Verdu. (2004). "Barrera a la Adopción de Mejores Practicas y Tecnología en la Industria de la aviación. Un Estudio de Caso.” Banco de México. Distrito Federal, Mexico.

Gasparini, L. (2000). "La Informalidad Laboral en la Argentina: Evolucion y Caracterizacion." La Economia Oculta en la Argentina. Fundacion de Investigaciones Economicas Latinoamericanas, Argentina. 162-223.

Geldstein, R. (2000) “Non-Labor Market Coping Strategies in Argentina” LCSPG/World Bank, draft.

Gill, Indermit S, Amit Dar, and Fred Fluitman (eds.). (2000). Vocational Education and Training Reform: Matching Skills to Markets and Budgets. New York: Oxford University Press.

Gill, Indermit S, Amit Dar, and Fred Fluitman. (1998). "Skills and Change: A Synthesis of Findings of a Multi-Country Study of Vocational Education and Training Reforms.” Departmental Working Paper No. 19790. Washington DC: The World Bank.

Gill, I. and N. Ilahi. (2000). "Economic Insecurity, Individual Behavior, and Social Policy.” Mimeographed. World Bank, Washington, D.C.

Gindling, T.H. and K. Terrell (2004) “Minimum wages, Inequality and Globalization “ IZA working paper 1160. Frankfurt.

Gong, X. and Van Soest A. (2002)."Wage Differentials and Mobility in the Urban Labor Market: A Panel Data Analysis for Mexico." Labour Economics 9 (4): 513-529.

Gonzaga, G. (2003) Labor Turnover and Labor Legislation in Brazil” Economia 4:1

Gonzalez, J. A. (1999) “Labor Market Flexibility 13 Latin American Countries and the U.S.” Wprld Bank Latin American Viewpoints Series.

Gonzalez de Rocha, M. (1994) The Resources of Poverty: Women and Survival in a Mexican City (Blackwell Publisher: Massachusetts).

Gracia, O. and M. Santamaría (Forthcoming). Colombian Productivity: Looking at the Main Stylized Facts and New Hypotheses, Mimeo. Washington, DC.

Grubb, D., W. Wells (1993), Employment Regulation and Patterns of Work in EC countries. OECD Economic Studies, Vol. 21, pp. 7-58.

Gruber, J.(1997) "The Incidence of Payroll Taxation: Evidence from Chile". Journal of Labor Economics 15(3),72-101. 
Guasch, J. L. (1999). “An Alternative to Traditional Unemployment Insurance Programs: A Liquidity-Based Approach against the Risk of Earnings Loss”, LCSFP/World Bank, unpublished manuscript

Hall, G. and H. Patrinos (2004). Indigenous People, Poverty and Human Development in Latin America: 1994-2004. World Bank, Washington, D.C.

Haro, V. (unpublished). Análisis de los efectos en inequidad de género de la regulación del trabajo en México, LCSPG. World Bank, Washington, D.C.

Heckman, J. and C. Pages (2004) Law and Employment, NBER Chicago

Hilger, N. G.. (2003). "Market Liberalization, Labor Unions and Real Wages in Mexico, 19841998.” Honor Thesis in Economics. Stanford University. Stanford, California.

Hobjin, B. and B. Jovanovic. (2001). “The Information Technology Revolution and the Stock Market: Evidence.” The American Economic Review, forthcoming.

Hopenhayn, H. and R. Rogerson. (1993). "Job Turnover and Policy Evaluation: A General Equilibrium Analysis." Journal of Political Economy. 101(5).

Inter-American Development Bank. (2003). "Ideas for Developement in the Americas. Vol. 1. Second Quarter. Research Department, IADB, Washington, D.C.

Inter-American Development Bank. (2004). Good Jobs Wanted: Labor Markets in Latin America.The John Hopkins University Press. Washington, D.C.

International Labour Organization (ILO). (2001). "Panorama Laboral 2001: America Latina y el Caribe." ILO, Geneva.

Krebs, T., P. Krishna and W. Maloney. (2004). "Trade Policy, Income Risk, and Welfare" World Bank, Washington, D.C.

Kugler, A. (2000). "The Incidence of Job Security Regulations on Labor Market Flexibility and Compliance in Colombia: Evidence from the 1990 Reform." Research Network Working paper R-393. Washington, D.C., United States: Inter-American Development Bank.

Lazear, E.. (1990). “Job Security Provisions and Employment.” Quarterly Journal of Economics 105 (3): 699-727.

Levenson, A. R. and W. F. Maloney. (1996). "The Informal Sector, Firm Dynamics, and Institutional Participation." Policy Research Paper No. 1988. World Bank, Washington, D.C.

López-Acevedo, G. (2004). "Wages and Productivity in Mexican Manufacturing.” Mexico City: The World Bank. Mimeo.

Maloney, W. F. (1998). “Are LDC Labor Markets Dualistic?” Washington, DC, United States: World Bank. Mimeographed document.

Maloney, W. F. 1999. "Does Informality Imply Segmentation in Urban Labor Markets? Evidence from Sectoral Transitions in Mexico." The World Bank Economic Review14(2):275-302.

Maloney, W. F. (2001). Self-Employment and Labor Turnover: Cross-Country Evidence. Proceedings, World Bank Economists Forum. World Bank, Washington, D.C.

Maloney (2003) “Evaluating Emergency Programs” mimeo, World Bank

Maloney, W.F (2002) “Trade Openness and Job Quality” background paper for de Ferranti et al. From Natural Resources to the Knowledge Economy 
Maloney, W.F. (2004) “Informality Revisited” World Development 32(7) 1159-1178.

Maloney, W., P. Fajnzylberg, and G. Montes. (2003). "Estimating the Effect of Formality as a Treatment on Micro-Firms." World Bank, Washington, D.C.

Maloney, W. and Nunez Mendez, J. (2004) "Measuring the Impact of Minimum Wages: Evidence from Latin America." In James Heckman \& Carmen Pages eds. "Law and Employment: Lessons from Latin America and the Caribbean,” U. Chicago Press and NBER

Maloney, W. and E. Pontual Rivero. (2001). "Employment and Wage Effects of Mexican Unions. A Case of Extreme Efficient Bargaining.” Mimeographed. World Bank. Washington, D.C.

Marcouiller, D., V. Ruiz de Castilla, and C Woodruff (1997) "Formal measures of the informal sector wage gap in México, El Salvador and Peru.” Economic Development and Cultural Change 45 (2):367-92.

Marquez, G. (1998) "Proteccion al empleo y funcionamiento del mercado de trabajo:una aproximacion comparativa” working paper, Office of the Chief Economist, Inter-American Development Bank, Washington, DC.

Marquez, G. (2002) “Training the Workforce in Latin America” What Needs to be Done?”, InterAmerican Development Bank, Washington DC, USA.

Marquez, G. and C. Pages. (1998). "Trade and Employment: Evidence from Latin America and the Caribbean." Research Department Working Paper No. 366. Inter American Development Bank, Washington, D.C.

Marrufo, G. M.. (2001). "Financing Social Security Programs in Mexico: Who Bears the Cost?." WP 135. Stanford Center for International Development Working Paper Series. Stanford, CA

McArdler and Blom (forthcoming) "Firm and Worker Training in the Caribbean”, World Bank Background Paper, Washington DC, USA and Kingston Jamaica

Menezes-Filho, N., H. Zylberstajn, J. P. Chahad, and E. Pazello. (2002). "Unions and the Economic Performance of Brazilian Establishments.” Working Paper R-464. Inter American Development Bank, Washington, D.C.

Mondino, G. and Montoya, S. (2002). “The Effects of Labor Market Regulations on Employment Decisions by Firms. Empirical Evidence for Argentina”, in Law and Employment: Lessons from Latin America and the Caribbean, James Heckman and Carmen Pagés Eds, forthcoming from The University of Chicago Press. Chicago, IL

Montenegro, Claudio (2001). "Wage Distribution in Chile: Does Gender Matter? A Quantile Regression Approach.” Policy Research Report on Gender and Development. Working Paper Series No. 20. The World Bank, Washington D.C.

Montenegro. C. and C. Pagés. (2003). "Who Benefits from Labor Market Regulations? Chile 19601998." NBER Working Paper No. w9850. Cambridge, MA.

Montes, G. and M. Santamaría. (Forthcoming). Productivity and Labor Markets in Mexico, Mimeo. Washington, DC.

Morduch, J. (1999) Between the Market and State: Can Informal Insurance Patch the Safety Net?' World Bank Research Observer14:187-207

Murillo, M. V., M. Tomassi, L. Ronconi, and J. Sanguinetti. (2002). "The Economic Effects of Unions in Latin America: Teachers’ Unions and Education in Argentina” Working Paper R-463. Inter American Development Bank, Washington, D.C. 
Nickell, S. (1997). "Unemployment and Labor Market Rigidities: Europe versus North America." Journal of Economic Perspectives 11(3): 55-74.

Nopo, H., J. Saavedra and M. Torero (2004) “Race and Earnings in a Mixed labor Market “ IZA Discussion Paper.

Nopo, H., M. Robles and J. Saavedra (2002) "Una medicion del Impacto del Programa de Capacitacion Laboral Juvenil PROJOVEN” Documento de Trabajo No. 36, GRADE, Lima.

Nicoletti , G. and S. Scarpetta (1999), "Product and labour market regulations and performance in the OECD labour markets”, OECD, Economics Department Working Paper, forthcoming.

Oaxaca, R. (1973) “Male-Female Wage Differentials in Urban Labor Markets” International Economic Review 14(3): 693-706.

Paes de Barros, R. and C. H. Corseuil.(2004). "The Impact of Regulations on Brazilian Labor Market Performance. In J. Heckman and C. Pages, eds., Law and Employment: Lessons from Latin America and the Caribbean. NBER, Cambridge, MA; and University of Chicago, Chicago, IL

Pagés, C. and Montenegro. C. (1999). "Job Security and the Age-Composition of Employment: Evidence from Chile." Working Paper 398. Washington, D.C., United States: Inter-American Development Bank.

Parente, S. L. and E. C. Prescott (1991). Technology Adoption and Growth. NBER Working Paper No 3733, Cambridge, MA.

Parente, S. L. and E. C. Prescott (2000). Barriers to Riches, MIT Press, Cambridge,M.A.

Rama, M. and D. MacIsaac. (1999). "Earnings and Welfare after Downsizing: Central Bank Employees in Ecuador." The World Bank Economic Review 13(1): 89-116.

Rodrick, D. 1997. "Has Globalization Gone Too Far?" Institute for International Economics.Washington, D.C.

Saavedra J., (2003) "Labor Markets in Latin America During the Nineties” in P.P. Kuczynski and J. Williamson (eds.) "After the Washington Consensus: Restarting Growth and Reform in Latin America, Institute of International Economics, Washington D.C.

Saavedra, J. and A. Chong (1999) "Structural Reform, Institutions and Earnings: Evidence from the Formal and Informal Sectors in Urban Perú” Journal of Development Economics, 35, 4: 95-116.

Saavedra, J. and M. Torero. (2002). "Union Density Changes and Union Effects on Firm Performance in Peru” Working Paper R-465. Inter American Development Bank, Washington, D.C.

Saavedra, J. and M. Torero. (2004) "Labor Market Reforms and their impact over formal labor demand and job market turnover: The case of Peru. In Heckman and Pages eds. Law and Employment, Lessons from Latin America and the Caribbean, NBER, Chicago.

Sanchez, S., A Joo and C. Zappala (2001) Constrained Global Integration: A Note on Microenterprises in Latin America, mimeo, World Bank.

Sargent, J. and L. Mattheuws. (1999). "Exploitation or Choice? Exploring the Relative Attractiveness of Employment in the Maquiladoras." Journal of Business Ethics 18:213-227.

Scarpetta, S. and Tressel (2004).Boosting Productivity via Innovation and Adoption of New Technologies: Any Role for Labor Market Institutions? World Bank Policy Research Working Paper 3273. Washington, DC. 
Schaffner, J. A.. 1998. " Premiums to Employment in Larger Establishments: Evidence from Peru." Journal of Development Economics 55 81-113.

Stallings, B. and W.Peres. (2000). Growth, Employment and Equity, The Impact of the Economic Reforms in Latin America and the Caribbean. Economic Commisions for Latin America and Caribbean. Washington, D.C.: The Brookings Institution Press.

Tannuri-Pianto, M., Pianto, D. and O. Arias (2004). “Informal Employment in Bolivia: A Lost Proposition?” Working Paper No. 236, Department of Economics. University of Brasilia.

Tannuri-Pianto, M. and D. Pianto (2002). “ Informal employment in Brazil - a choice at the top and segmentation at the bottom: a quantile regression approach”, Working paper no 236, Department of Economics, University of Brasilia.

Tan, Hong, and G. Batra. (1995). "Enterprise Training in Developing Countries: Overview of Incidence, Determinants, and Productivity Outcomes.” Private Sector Development Department Occasional Paper No. 9. Washington DC: The World Bank.

Tan, Hong, and G. Batra. (1997). "Technology and Firm Size-Wage Differentials in Colombia, Mexico, and Taiwan (China).” In: The World Bank Economic Review 11(1): 59.84.

Tan, Hong, and G. Lopez-Acevedo. (2003). "Mexico: In-Firm Training for the Knowledge Economy.” Policy Research Working Paper No. 2957. Washington DC: The World Bank.

Urizar, C. H. and S. Lee. (2003). "The Effects of Unions on Productivity: Evidence from Large Coffee Producers in Guatemala.” Working Paper R-473. Inter American Development Bank, Washington, D.C.

Weller, J. (2000) "Reformas Economicas, Crecimiento y Empleo: Los Mercados del Trabajo en America Latin y el Caribe, Fondo de Cultura Economica, CEPAL, Santiago, Chile.

Wodon, Q and C. Siaens. (1999). “Training for the Urban Unemployed: A Reevaluation of Mexico’s Probecat” in World Bank (ed) Government Programs and Poverty in Mexico, Report No. 19214-ME.

World Bank. (2000). Mexico. Export Dynamics and Productivity: Analysis of Mexican Manufacturing in the 1990s. Report No. 19864-ME. Washington DC: The World Bank.

World Bank (2001a) Household Risk, Self-Insurance and Coping Strategies in Urban Argentina, World Bank Report No. 22426-AR.

World Bank. (2001b). Mexico. Technology, Wages and Employment. Report No. 22797-ME. Washington DC: The World Bank.

World Bank. (2003). Mexico. Technical Education and Training: Issues and Options. Report No. 27506-ME. Washington DC: The World Bank. Mimeo.

World Bank. (2004a). Public Training Reform Issues in Colombia: The Case of SENA. Report No. 27752. Washington DC: The World Bank. Mimeo.

World Bank. (2004b). How well do SME Programs Work? Evaluating Mexico’s SME Programs Using Panel Firm Data. Washington DC: The World Bank. Mimeo.

Zegarra, E. and R. Ravina. (2003). "Teacher Unionization and the Quality of Education in Peru: An Empirical Evaluation Using Survey Data.” Working Paper R-474. Inter American Development Bank. Washington, D.C. 